\title{
SPARUS MELANOPTERUS.
}

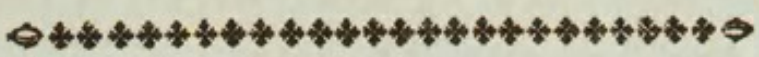

\section{CHARACTER GENERICUS.}

Dentes validi: Primores duplici, triplici, vel quadruplici ordine dispositi.

Molares (plerisque) validi, convexi, læves, in series dispositi, et quasi pavimentum in ore efformantes.

Labia crassa : Opercula mutica, squamosa.

\section{CHARACTER SPECIFICUS, छैc.}

SPARUS purpurascens, abdomine flavo-virente, orbitis viridi-radiatis, pinnis nigris. LABRUS MELAPTERUS. L. Pinnis nigris, aculeis dorsalibus octo.

Bloch. t. 285.

Maria incolit Indica Sparus melanopterus, longitudine, ut plurimum, pedali. 


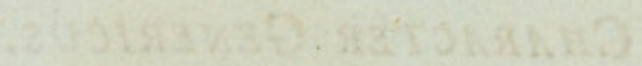

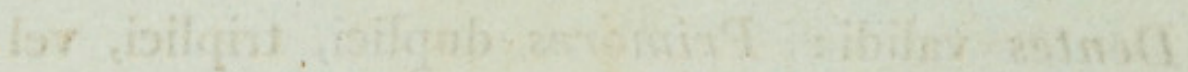

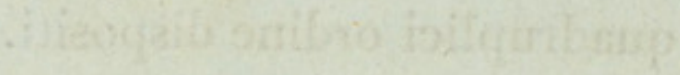

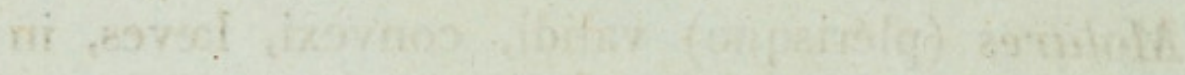

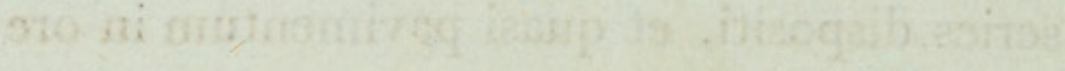

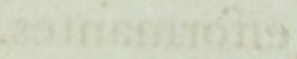

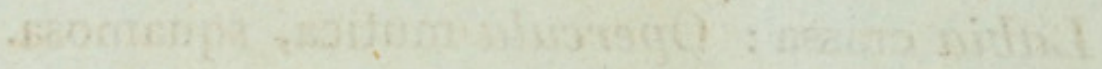

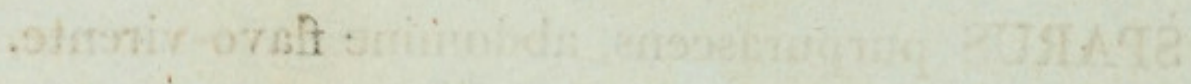

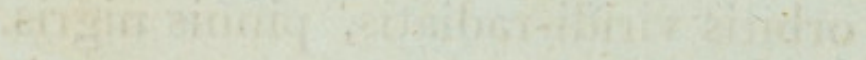

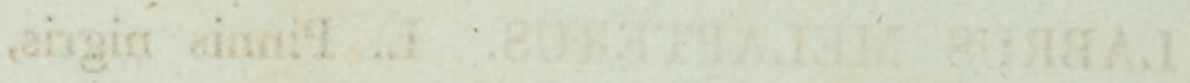

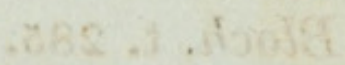

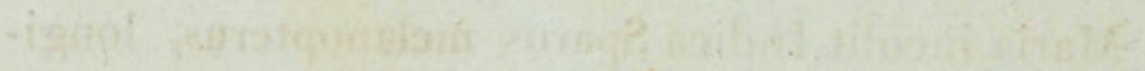

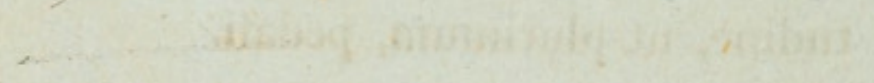


i 


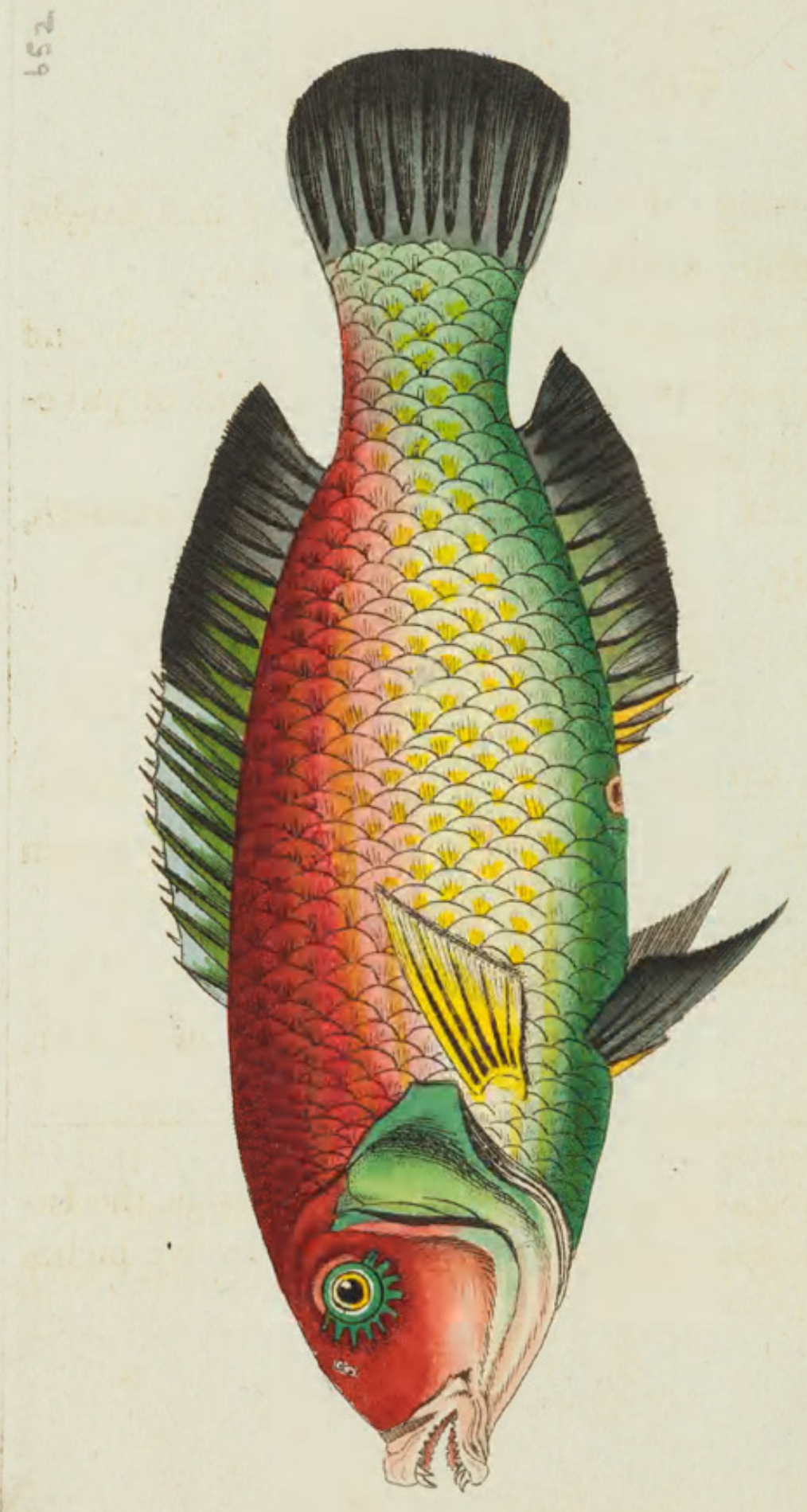




\title{
BLACK-FINNED SPARUS.
}

\author{
$4 * * * * * * 4 * * * * * * * * *$ \\ GENERIC CHARACTER.
}

Teeth strong ; Front-Teeth disposed in a single, double, treble, or quadruple row.

Grinders (in most species) convex, smooth, and disposed in ranges, forming a kind of pavement in the mouth.

Lips thick: Gill-Covers unarmed, smooth, scaly.

\section{$S_{P E C I F I C}$ CHARAGTER, Ec.}

Purplish SPARUS, with yellowish-green abdomen, orbits of the eyes radiated by green streaks, and black fins.

Black-Finned SPARUS.

Gen. Zool. 4. p. 451.

The black-finned Sparus is seen chiefly in the Indian seas, and usually measures about twelve inches in length. 


\section{$2 \mathrm{BHL}$ Biodiversity Heritage Library}

Shaw, George. 1804. "The Black-Finned Sparus, Sparus melanopterus [PI. 652]." The Naturalist's Miscellany 16(CLXXXIV), https://doi.org/10.5962/p.311093.

View This Item Online: https://www.biodiversitylibrary.org/item/281942

DOI: https://doi.org/10.5962/p.311093

Permalink: https://www.biodiversitylibrary.org/partpdf/311093

\section{Holding Institution}

Museums Victoria

\section{Sponsored by}

Atlas of Living Australia

\section{Copyright \& Reuse}

Copyright Status: Public domain. The BHL considers that this work is no longer under copyright protection.

This document was created from content at the Biodiversity Heritage Library, the world's largest open access digital library for biodiversity literature and archives. Visit BHL at https://www.biodiversitylibrary.org. 